\title{
PENINGKATAN KEMAMPUAN GURU DALAM PENERAPAN PEMBELAJARAN KONTEKSTUAL MELALUI FOCUS GROUP DISCUSSION (FGD)
}

\author{
Reti Bala \\ Pengawas SMK Dinas DIKBUDPORA Provinsi Gorontalo
}

\begin{abstract}
Abstrak
Pengawas Sekolah adalah pejabat fungsional yang berkedudukan sebagai pelaksana teknis dalam melakukan pengawasan pendidikan terhadap satuanpendidikan. Salah satu pendekatan pembelajaran yang dikembangkan dalam kurikulum 2006 (KTSP) adalah pendekatanPembelajaran Kontekstual.Hal ini semakin penting setelah diberlakukannya kurikulum 2013 yang lebih menekankan pembelajaran bermakna bagi siswa dalam semua kompetensi dasardenganmenggunakan pendekatan kontekstual atau yang disebut dengan Contextual Teaching and Learning (CTL).Dari hasilpenelitian yang dilakukanpada guru-guru SMK 1 BatudaabahwaTeknik Focus Group Discussion (FGD) dapat meningkatkan kemampuan guru dalam menerapkan pembelajaran kontekstual, hal ini dapat dibuktikan dari hasil pelaksanaan tindakan sampai pada siklus III terjadi peningkatan yang cukup signifikan, yaitu rata-rata dari siklus I $(2,90)$, siklus II $(3,46)$ dan pada siklus III menjadi rata-rata 4,15 . Jikadipresentasikanterjadipeningkatan 19,31\% darisiklus I kesiklus II serta $19.94 \%$ kesiklus III atau katagori 'baik', dan bahkan sudah mendekati target ketercapaian kemampuan guru dalam menerapkan pembelajaran kontekstual.
\end{abstract}

Kata Kunci :Kurikulum 2013, Contextual Teaching and Learning (CTL), Focus Group Discussion (FGD)

\section{A.PENDAHULUAN}

Pengawas sekolah merupakan salah satu tenaga kependidikan yang memegang peran strategis dalam meningkatkan profesionalisme guru dan mutu pendidikan di sekolah karena Pengawas Sekolah adalah pejabat fungsional yang berkedudukan sebagai pelaksana teknis dalam melakukan pengawasan pendidikan terhadap satuanpendidikan. Tugas pengawasan yang dimaksud adalah melaksanakan kegiatan pengawasan akademik dan manajerial. Hal ini seiring dengan Permen PAN dan RB Nomor 14 Tahun 2016 tentang Perubahan atas Permen PAN dan RB Nomor 21Tahun 2010 tentang Jabatan Fungsional Pengawas Sekolah dan Angka Kredit nya pasal 5 menyatakan bahwa tugas pokok Pengawas

Pedagogika.fup@ung.ac.id
Sekolah adalah melaksanakan tugas pengawasan akademik dan manajerial pada satuan pendidikan.Di pihak lain, guru sendiri belum banyak yang mengikuti perkembangan ilmu pendidikan, termasuk masalah pendekatan Pembelajaran Kontekstual (PK). Salah satu pendekatan pembelajaran yang dikembangkan dalam kurikulum $2006 \quad$ (KTSP) adalah pendekatanPembelajaran Kontekstual.Hal ini semakin penting setelah diberlakukannya kurikulum 2013 yang lebih menekankan pembelajaran bermakna bagi siswa dalam semua kompetensi dasardenganmenggunakan pendekatan kontekstual atau yang disebut dengan Contextual Teaching and Learning (CTL).Empatperubahanbesardarikurikulum 2006 dikembangkankekurikulum 2013 
yaitukonsepkurikulum yang menyeimbangkanhardskilldansoftskill, buku yang dipakaiberbasiskegiatan, proses pembelajaranserta proses pembelajaran. Namun demikian sejauh ini pendidikan kita masih didominasi oleh pandangan bahwa pengetahuan sebagai perangkat fakta-fakta yang harus dihafal. Kelas masih berfokus pada guru sebagai sumber utama pengetahuan, kemudian ceramah menjadi pilihan utama strategi belajar.Berdasarkan uraian di atas, maka penulis selaku pengawas sekolah tertarik untuk melakukan atau mengadakan Penelitian Tindakan yang berjudul "Meningkatkan Kemampuan Guru dalam Menerapkan Pembelajaran Kontekstual Melalui Focus Group Discussion (FGD) Pada SMK Negeri 1 Batudaa Kabupaten Gorontalo".

\section{B.KAJIAN TEORI}

\section{A. Pembelajaran Kontekstual}

Pembelajaran Kontekstual adalah konsep belajar yang membantu guru mengaitkan antara materi yang diajarkan dengan situasi dunia nyata siswa dan mendorong siswa membuat hubungan antara pengetahuan yang dimilikinya dengan penerapannya dalam kehidupan mereka sehari-hari, dengan melibatkan tujuh komponen utama pembelajaran efektif, yakni: Constructivism, Questioning, Inquiry, Learning Community, Modelling, dan Authentic Assesment.(Depdiknas, 2002).

B. Kurikulum 2013

1. KonsepKurikulum

Penyempurnaan Pola Pikir Perumusan Kurikulum 2013 yaitu standar isi diturunkan dari Standar Kompentensi Lulusan melalui kompetensi inti yang bebas mata pelajaran

2. Buku

Pedagogika.fup@ung.ac.id
Dalam KK2013, Buku ditulis mengacu kepada konsep kurikulum (KI, KD, Silabus)

3. Proses Pembelajaran

Setiap pembelajaran menggunakan pendekatan saintifik untuk meningkatkan kreativitas peserta didik melalui proses mengamati, menanya, mencoba, menalar, mencipta, dan mengkomunikasikan untuk meningkatkan kreativitas peserta didik. Disamping itu, dibiasakan bagi peserta didik

\section{Proses Penilaian}

Mengukurtingkatberfikirsiswamulaidari rendahsampaitinggidanmengukur proses kerjasiswa, bukan hanya hasil kerja siswa menggunakan portofolio pembelajaran siswa.

\section{Focus Group Discussion (FGD)}

Focus Group Discussion (FGD) adalah suatu kegiatan yang berupa diskusi terarah yang dilakukan secara kelompok. (Petunjuk Teknis School Action Research Depdiknas 2007). Melalui teknik supervisi FGD ini, dilakukan sosialisasi tentang pembelajaran kontekstual, dan juga dapat digunakan untuk sharing antara peneliti dengan peserta maupun antar peserta FGD. Melalui teknik ini yang dilakukan secara berkesinambungan, pendekatan kontekstual mampu meningkatkan kemampuan guru dalam pembelajaran kontekstual.

\section{C.METODE PENELITIAN}

Penelitian ini merupakan penelitian tindakan di SMK Negeri 1 Batudaa, dengan subyek penelitian adalah 12 orang guru produktif, sehingga jenis penelitiannya dirancang dengan menggunakan Penelitian Tindakan Sekolah (PTS) atau School Action Research (SAR). Penelitian tindakan adalah suatu

P-ISSN : 2086-4469 E-ISSN : 2716-0580 
PEDAGOGIKA

Jurnal Ilmu Pendidikan

Volume 9 (Nomor 2) 2018

pengkajian terhadap suatu permasalahan dengan ruang lingkup yang tidak terlalu luas yang berkaitan dengan perilaku seseorang atau kelompok orang tertentu, disertai dengan penelaahan yang diteliti terhadap suatu perlakuan tertentu dan mengkaji sejauh mana dampak perlakuan itu terhadap perilaku yang sedang diteliti (Nata Wijaya, 1997).

Penelitian ini menggunakan perpaduan antara teknik analisis data kualitatif dan teknik analisis data kuantitatif karena sebagian data yang diperoleh berupa data kuantitatif.Sedangkan analisis data kuantitatif dalam penelitian ini akan menggunakan analisis data dengan jenis statistik deskriptif karena adanya data-data kemampuan guru yang dihitung berdasarkan hasil pengamatan yang berupa skala nilai dan dimasukkan dalam tabel-tabel. Ada dua jenis skala penilaian berdasarkan deskriptor dari setiap indikator kemampuan mengajar guru yang dinilai, yaitu deskriptor yang berdiri sendiri dan deskriptor yang berjenjang. Skala penilaian untuk deskriptor yang berdiri sendiri dibuat berdasarkan kemunculan deskriptor. Nilai 1 pada deskriptor yang berdiri sendiri berarti tidak ada satu deskripsipun yang nampak pada indikator penilaian kemampuan guru. Nilai 2 berarti hanya ada satu deskriptor yang tampak, Nilai 3 berarti ada 2 deskriptor yang tampak pada pengamatan dan seterusnya sampai kepada skala penilaian 5. Untuk deskriptor yang berjenjang, skala penilaiannya mengikuti jenjang deskriptor tersebut. Skala 1 berarti apabila deskriptor yang tampak sesuai dengan indikator yang telah disediakan (indikator jenjang), yang berarti nilai kemampuan guru tersebut adalah 1. Apabila deskriptor yang nampak sesuai dengan deskriptor berskala 2, maka kemampuan guru pada indikator tersebut adalah 2. Demikian seterusnya sampai indikator yang ke-5.

\section{D.HASIL PENELITIAN}

Hasil Penelitian pada Siklus I

Sebagai gambaran hasil penelitian dengan subyek 12 orang guru di SMK Negeri 1 Batudaa, sebagaimana terdapat dalam tabel 1dan 2 .

Tabel 1 Data Skor Hasil Penerapan Pembelajaran Kontekstual Melalui FocusGroupDiscussion (FGD)Pada Siklus I

\begin{tabular}{|c|c|c|c|c|c|c|c|c|}
\hline \multirow{2}{*}{$\begin{array}{c}\text { Kode } \\
\text { Guru }\end{array}$} & \multicolumn{6}{|c|}{ Skor Hasil Pengamatan Per Komponen } \\
\cline { 2 - 9 } & A & B & C & D & E & F & G & $\begin{array}{c}\text { Rata- } \\
\text { rata }\end{array}$ \\
\hline 01 & 3 & 3 & 3 & 3 & 2 & 3 & 3 & 2.86 \\
\hline 02 & 3 & 3 & 2 & 3 & 3 & 3 & 3 & 2.86 \\
\hline 03 & 3 & 3 & 3 & 4 & 2 & 3 & 3 & 3.00 \\
\hline 04 & 3 & 2 & 3 & 3 & 3 & 2 & 3 & 2.71 \\
\hline 05 & 3 & 2 & 4 & 3 & 3 & 3 & 3 & 3.00 \\
\hline 06 & 3 & 3 & 3 & 3 & 2 & 3 & 3 & 2.86 \\
\hline 07 & 2 & 3 & 4 & 3 & 3 & 4 & 3 & 3.14 \\
\hline 08 & 3 & 2 & 3 & 3 & 2 & 3 & 3 & 2.71 \\
\hline 09 & 3 & 3 & 3 & 4 & 2 & 3 & 2 & 2.86 \\
\hline 10 & 2 & 3 & 3 & 3 & 3 & 4 & 3 & 3.00 \\
\hline 11 & 3 & 3 & 3 & 2 & 3 & 3 & 3 & 2.86 \\
\hline 12 & 3 & 3 & 3 & 3 & 3 & 3 & 3 & 3.00 \\
\hline $\begin{array}{c}\text { Rata- } \\
\text { Rata }\end{array}$ & $\mathbf{2 , 8 6}$ & $\mathbf{2 , 9 3}$ & $\mathbf{3 , 0 0}$ & $\mathbf{2 , 9 3}$ & $\mathbf{2 , 8 0}$ & $\mathbf{2 , 9 3}$ & $\mathbf{2 , 8 0}$ & $\mathbf{2 , 8 8}$ \\
\hline
\end{tabular}

Keterangan:

$\mathrm{A}=$ Melakukan konstruksi dalam pembelajaran

$\mathrm{B}=$ Melakukan inkuiri dalam pembelajaran

$\mathrm{C}=$ Adanya questioning dalam proses pembelajaran

$\mathrm{D}=$ Adanya learning community atau belajar kelompok dalam pembelajaran

$\mathrm{E}=$ Adanya modelling dalam pembelajaran

$\mathrm{F}=$ Dilakukan refleksi di akhir pembelajaran

$\mathrm{G}=$ Adanya authentic assesment dalam proses dan akhir pembelajaran 
Dari tabel I ditunjukkan bahwa kemampuan guru dalam menerapkan pembelajaran kontekstual pada siklus I masih rendah, yaitu dengan rata-rata 2,90 atau katagori 'kurang'. Jenis kemampuan yang paling rendah dari pengamatan siklus I yaitu melakukan inkuiri dalam pembelajaran, dengan rata-rata 2,75 (kurang). Sedangkan beberapa kemampuan yang memiliki skor tinggi yaitu adanya questioning dalam proses pembelajaran, adanya learning community atau belajar kelompok dalam pembelajaran, serta dilakukannya refleksi di akhir pembelajaran dengan skor 3,08.

Sedangkan dari tabel 2, dapat kita lihat bahwa pada siklus I yang berkemampuan sangat baik 0\%, baik 7,14\%, cukup $64,28 \%$, kurang $16,67 \%$, dan sangat kurang $0 \%$. Berdasarkan hasil penilaian pada siklus, menunjukkan bahwa kemampuan guru SMK 1 Batudaa dalam pembelajaran kontekstual belum sesuai target pembelajaran, oleh sebab itu perlu diidentifikasi lebih lanjut mengenai hambatan yang ada dan kemudian diperbaiki pada siklus II.

Hasil Penelitian pada siklus II

Sebagai gambaran hasil penelitian dengan obyek 12orang guru, sebagaimana terdapat dalam tabel II.

Tabel 2 Data Skor Hasil Penerapan

Pembelajaran Kontekstual Melalui Melalui Focus Group Discussion (FGD)Pada Siklus II

\begin{tabular}{|c|c|c|c|c|c|c|c|c|}
\hline \multirow{2}{*}{$\begin{array}{c}\text { Kode } \\
\text { Guru }\end{array}$} & \multicolumn{6}{|c|}{ Skor Hasil Pengamatan Per Komponen } \\
\cline { 2 - 9 } & A & B & C & D & E & F & G & $\begin{array}{c}\text { Rata- } \\
\text { rata }\end{array}$ \\
\hline 01 & 3 & 3 & 4 & 4 & 3 & 4 & 3 & 3.43 \\
\hline 02 & 4 & 3 & 3 & 4 & 4 & 3 & 4 & 3.57 \\
\hline 03 & 3 & 4 & 3 & 4 & 2 & 4 & 3 & 3.29 \\
\hline 04 & 3 & 3 & 4 & 4 & 3 & 3 & 4 & 3.43 \\
\hline 05 & 4 & 3 & 4 & 3 & 4 & 3 & 4 & 3.57 \\
\hline
\end{tabular}

\begin{tabular}{|c|c|c|c|c|c|c|c|c|}
\hline 06 & 3 & 3 & 4 & 3 & 3 & 3 & 4 & 3.29 \\
\hline 07 & 3 & 3 & 4 & 3 & 4 & 4 & 3 & 3.43 \\
\hline 08 & 4 & 3 & 4 & 3 & 4 & 3 & 4 & 3.57 \\
\hline 09 & 4 & 3 & 3 & 4 & 3 & 4 & 3 & 3.43 \\
\hline 10 & 4 & 4 & 3 & 4 & 4 & 4 & 3 & 3.71 \\
\hline 11 & 3 & 4 & 4 & 3 & 3 & 4 & 4 & 3.57 \\
\hline 12 & 4 & 4 & 3 & 3 & 4 & 2 & 3 & 3.29 \\
\hline $\begin{array}{c}\text { Rata- } \\
\text { Rata }\end{array}$ & $\mathbf{3 , 5 0}$ & $\mathbf{3 , 3 3}$ & $\mathbf{3 , 5 8}$ & $\mathbf{3 , 5 0}$ & $\mathbf{3 , 4 2}$ & $\mathbf{3 , 4 2}$ & $\mathbf{3 , 5 0}$ & $\mathbf{3 , 4 6}$ \\
\hline
\end{tabular}

Dari tabel 2 dapat dilihat bahwa pada umumnya kemampuan guru dalam menerapkan proses pembelajaran kontekstual adanya peningkatandarisiklus I ke siklus II, yaitu dengan rata-rata 3,46 atau katagori 'cukup'. Jenis kemampuan. yang paling rendah sama seperti aspek pada siklus sebelumnya yaitu melakukan inkuiri dalam pembelajaran dengan skor 3,33. Sedangkan jenis kemampuan yang paling baikyaitu adanya questioning dalam proses pembelajaran.Selain itu juga terjadi peningkatan skor di semua jenis kemampuan guru.

Sedangkan dari tabel IV, dapat dilihat bahwa pada siklus II ini yang berkemampuan sangat baik $0 \%$, baik $50,42 \%$, cukup $48,81 \%$, dan kurang 2,38\%, dan sangat kurang 0,0 \%.Dari presesntase masing-masing kategori pada siklus II ini, menunjukkan bahwa kemampuan guru dalam pembelajaran kontekstual sudah terjadi peningkatan. Namun demikian peningkatan tersebut belum menunjukkan kondis yang baik, sehingga masih diperlukan upaya-upaya untuk meningkatkan pencapaian yang diinginkan.

Hasil Penelitian pada siklus III

Sebagai gambaran hasil penelitian dengan subyek 12 orang guru, sebagaimana terdapat dalam tabel III. 
PEDAGOGIKA

Jurnal Ilmu Pendidikan

Volume 9 (Nomor 2) 2018

Tabel 3 Data Skor Hasil Penerapan Pembelajaran Kontekstual Melalui Focus Group Discussion (FGD)Pada Siklus III

\begin{tabular}{|c|c|c|c|c|c|c|c|c|}
\hline \multirow{2}{*}{$\begin{array}{c}\text { Kode } \\
\text { Guru }\end{array}$} & \multicolumn{6}{|c|}{ Skor Hasil Pengamatan Per Komponen } \\
\hline 01 & 5 & 4 & 5 & 4 & 4 & 4 & 3 & 4.14 \\
\hline 02 & 4 & 3 & 4 & 5 & 5 & 3 & 4 & 4.00 \\
\hline 03 & 4 & 3 & 3 & 5 & 5 & 4 & 4 & 4.00 \\
\hline 04 & 4 & 3 & 5 & 5 & 4 & 4 & 4 & 4.14 \\
\hline 05 & 5 & 4 & 5 & 4 & 4 & 4 & 4 & 4.29 \\
\hline 06 & 4 & 4 & 4 & 4 & 5 & 5 & 4 & 4.29 \\
\hline 07 & 4 & 4 & 5 & 5 & 4 & 4 & 4 & 4.29 \\
\hline 08 & 4 & 4 & 5 & 4 & 5 & 4 & 3 & 4.14 \\
\hline 09 & 5 & 4 & 3 & 5 & 5 & 4 & 4 & 4.29 \\
\hline 10 & 4 & 4 & 5 & 5 & 4 & 4 & 4 & 4.29 \\
\hline 11 & 3 & 4 & 4 & 5 & 4 & 4 & 4 & 4.00 \\
\hline 12 & 4 & 4 & 5 & 4 & 4 & 3 & 4 & 4.00 \\
\hline $\begin{array}{l}\text { Rata- } \\
\text { Rata }\end{array}$ & $\mathbf{4 , 1 7}$ & $\mathbf{3 , 7 5}$ & $\mathbf{4 , 4 2}$ & $\mathbf{4 , 5 8}$ & $\mathbf{4 , 4 2}$ & $\mathbf{3 , 9 2}$ & $\mathbf{3 , 8 3}$ & $\mathbf{4 , 1 5 s}$ \\
\hline
\end{tabular}

Dari tabel 3 dapat kita lihat bahwa kemampuan guru dalam menerapkan pembelajaran kontekstual pada siklus III sudah ada peningkatan yang cukup signifikan, yaitu dengan rata-rata 4,15 atau katagori 'baik'. Hal ini menunjukkanbahwa target ketercapaian kemampuan guru dalam menerapkan

pembelajaran kontekstualdapatdicapaidenganbaik. Jenis kemampuan yang paling rendah adalah masih tetap dengan siklus II yaitu melakukan inkuiri dalam pembelajaran, namun aspek ini telah mengalami peningkatan dari siklus-siklus sebelumnya dengan rata-rata pada siklus II 3,33 (cukup) menjadi 3,75 (cukup). Sedangkan jenis kemampuan yang paling baik ketercapaiannya yaitu adanya learning community atau belajar kelompok dalam pembelajaran dengan skor 4,58.

Disamping itu juga terjadi peningkatan skor di semua jenis kemampuan guru jika dibandingkan dengan siklus II. Sedangkan dari tabel VI, dapat kita lihat bahwa pada siklus III yang berkemampuan sangat baik $13,09 \%$, baik 50,11\%, cukup 26,19\%, kurang $0,00 \%$, dan sangat kurang 0,00 $\%$.Berdasarkan hasil penelitian pada siklus III, menunjukkan bahwa kemampuan guru dalam pembelajaran kontekstual memiliki peningkatan yang cukup signifikan, dan bahkan sudah mendekati ketercapaian target yang diharapkan dalam penelitian tindakan ini. Dengan demikian penelitian tindakan yang sudah sampai pada siklus III ini dianggap sudah cukup dan tidak perlu lagi dilakukan siklus IV.

Kesimpulan

Berdasarkan hasil Penelitian Tindakan Sekolah (PTS) tentang penerapan Pembelajaran Kontekstual (CTL) melalui teknik Focus Group Discussion (FGD) dapat disimpulkan sebagai berikut :

1. Upaya pengawas sekolah dalam melakukan teknik Focus Group Discussion (FGD) kepada guru mampu meningkatkan kemampuan dan ketrampilan guru dalam proses pembelajaran dengan menerapkan pendekatan Pembelajaran Kontekstual.

2. Semakin intensif melakukan Focus Group Discussion (FGD) bersama para guru mata pelajaran oleh pengawas sekolah, semakin meningkatkan kemampuan guru dalam menerapkan pendekatan pembelajaran kontekstual.

3. Pendekatan pembelajaran kontekstual sangat sesuai untuk menumbuhkan kekritisan siswa dalam menganalisis, membedakan, menggeneralisasikan, dan menghipotesis permasalahan

4. Teknik Focus Group Discussion (FGD) dapat meningkatkan kemampuan guru dalam menerapkan pembelajaran kontekstual, hal ini dapat dibuktikan dari hasil pelaksanaan tindakan sampai

P-ISSN : 2086-4469 E-ISSN : 2716-0580 
pada siklus III terjadi peningkatan yang cukup signifikan, yaitu rata-rata dari siklus I $(2,90)$, siklus II $(3,46)$ dan pada siklus III menjadi rata-rata 4,15 . Jikadipresentasikanterjadipeningkatan1 9,31\% darisiklus I kesiklus II serta 19.94\% kesiklus III atau katagori 'baik', dan bahkan sudah mendekati target ketercapaian kemampuan guru dalam menerapkan pembelajaran kontekstual. Di samping itu juga terjadi peningkatan skor di semua jenis kemampuan guru jika dibandingkan dengan siklus II.

5. Terjadi peningkatakan kategori sangat baik dari siklus II kesiklus III yaitu mencapai $13,09 \%$ dari $0,00 \%$ guru yang mencapaikategoriinipadasiklus II, guru yang berkemampuan baik mencapai $50,11 \%$ (menurun $0,2 \%$ jika dibanding siklus II)karenabanyak guru yang dapat meningkatkan kemampuannya menjadi kategori sangat baik,sedangkan guru yang berkemampuan cukup 26,19\% (menurun 46,32\% jika dibanding siklus II), guru yang berkemampuan kurang menurun dari $100 \%$ pada siklus II menjadi $0,00 \%$ pada siklus III, dan guru yang berkemampuan sangat kurang 0,00 $\%$.

\section{REFERENCES}

Depdikbud, 1997, Alat Penilaian Kemampuan Guru, Dirjen Dikdasmen, Direktorat Pendidikan Guru dan Tenaga Teknis, Jakarta, Proyek Peningkatan Mutu Guru SD setara D-ll.

Departemen Pendidikan Nasional (2002), Pendekatan Kontekstual (Contextual Teaching and Learning), Jakarta.
Departemen Pendidikan Nasional. 2007, Petunjuk Teknis Penelitian Tindakan Sekolah, Jakarta.

KementrianPendidikandanKebudayaan. 2014. Konsep dan Implementasi Kurikulum 2013. Jakarta (https://kemdikbud.go.id/kemdikbud/do kumen/Paparan/Paparan\%20Wamendik. pdf, diakses 2 Maret 2018)

Muhajir, N. 1996/1997. Pedoman Penelitian Tindakan Kelas (PTK) Bagian Ke 4 : Analisis dan Refleksi.

PresidenRepublik Indonesia.2017. Perubahan Atas Peraturan Pemerintah Nomor 74 Tahun 2008 Tentang Guru.Jakarta 